\title{
Toxicity and composition of paralytic shellfish poison (PSP) of toxificated bivalves in Ibaraki, Japan
}

\author{
Ritsuko MURAKami*1, Kazunori Yamamoto*1, and Tamao NoGUCHI*2 \\ 村上りつ子*1, 山本 和則*1, 野口 玉雄*2: \\ 茨城県産二枚貝の麻痺性貝毒について
}

Paralytic shellfish poison (PSP) infestation to bivalves due to toxic dinofllagate such as Alexandrium spp. has posed some serious problem on public health and fishery industry. Although their PSP infestation cannot be predicted completely, their PSP monitoring programs have been carried out to protect the consumer and the rear-farmer, from food poisoning and fishery damage, respectively, by the concerning prefectural agency. Therefore, three species of bivalves (mussel Mytilus edulis, hard clam Meretrix lamarckii, surf clam Pseudocardium sachalinensis) in Ibaraki were investigated on their toxicity and PSP composition, from 1990 to 1998 and for four successive years from 1993 to 1996 as well as in 1998, respectively. Further, in order to elucidate their toxification and detoxification mechanisms, the toxicity and PSP composition were investigated using anatomical parts of clams.

\section{Materials and Methods}

Materials Both of mussel and hard clam, and surf clam were collected, every year from 1990 to 1998 and from 1993 to 1998, respectively. Mussel and most of hard clam, and most of surf clam were collected, at Kashima and at Kujihama in Ibaraki Pref., Japan, respectively (Fig. 1). Assaay of toxicity Toxicity value was determined by means of mouse assay ; AOAC method ${ }^{1)}$ and the Japanese official method for $\mathrm{PSP}^{2}$, using the digestive glands, other parts and whole edible parts.

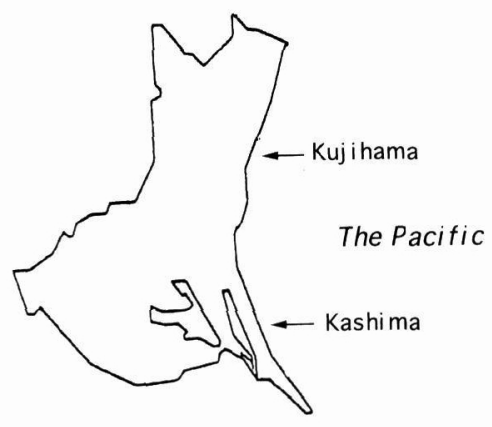

Fig. 1 Sampling sites in lbaraki.

*1 Ibaraki Prefectural Institute of Public Health, 993-2, Kasaharacho, Mito 310-0852, Japan 茨城県衛生研究所 $\overline{7} 310-0852$ 水戸市笠原町 993-2

*2 Faculty of Fisheries, Nagasaki University 1-14, Bunkyo, Nagasaki 852-8131, Japan 長崎大学水産学部 ₹852-8131 長崎市文教町 1-14 
Determination of PSP composition Three volumes of $80 \% \mathrm{EtOH}$ adjusted to $\mathrm{pH} 3.5$ was added to $10 \mathrm{~g}$ of each material and homogenated. The homogenate was centrifuged at $3000 \times \mathrm{g}$ for $15 \mathrm{~min}$. This procedure was repeated two more times. The supernatants obtained were combined, concentrated under the reduced pressure and then defatted with dichloromethan followed by subjection to a cartridge column of Sep-Pak C18 (Waters, USA). The solution obtained was analyzed for PSP components by post column derivatization high performance liquid chromatographic (HPLC) method with fluorometric detector ${ }^{3)}$. On the other hand, according to the AOAC method for PSP ${ }^{1)}$, the solution obtained was hydrolyzed with diluted hydrocloric acid in boiling water for $15 \mathrm{~min}$ and then analyzed for protogonyautoxins (PXs, C toxin group) to estimate the value for $\mathrm{PX}(\mathrm{C})$ by subtraction the value for GTX before hydrolysis from that after it.

\section{Results and discussion}

Bivalves tested were toxic every or every other year from 1990 to 1998 . They were toxic late in March or early in April and showed the highest score of toxicity in April and then became nontoxic middle or late in May, in common with each bivalve in each year except in 1998 where

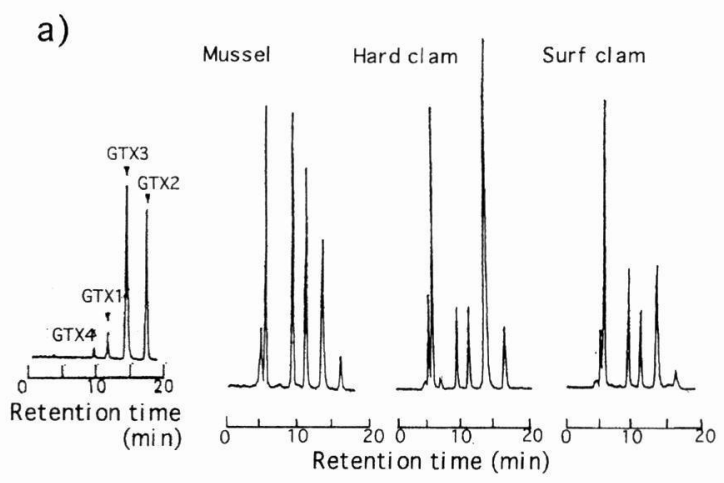

b)

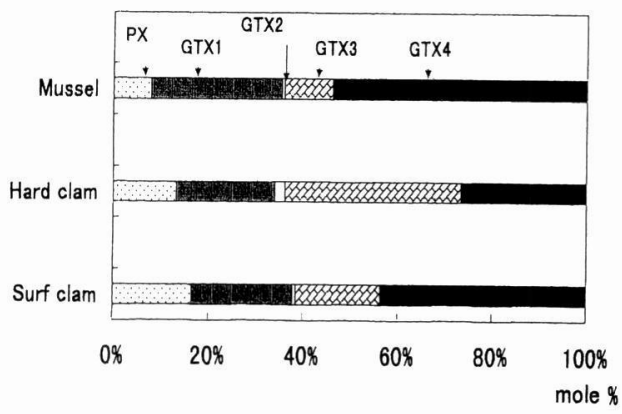

Fig. 2 PSP profiles of three species of bivalves.

a) HPLC chromatograms.

b) PSP composition mole ratio. 
PSP toxification of bivalves occurred a few weeks earlier than usual time. But some difference by species in the transition curve gradient of toxicity value were recognized. Mussel kept toxicity for the longest period among the three species. The difference in the rise and fall of toxicity was found between the hard clam and the surf clam. The gradient in the surf clam was steeper than in the hard clam. The toxicity score was the highest in the digestive gland of three bivalve species, ranging from 100 to $300 \mathrm{MU} / \mathrm{g}$ : $299.2 \mathrm{MU} / \mathrm{g}$ in the mussel on April 17, 1991, 107.3 $\mathrm{MU} / \mathrm{g}$ in the hard clam on April 25, 1995 and $212.1 \mathrm{MU} / \mathrm{g}$ in the surf clam on April 16, 1996, respectively. Toxicity of each parts of two species of clams was also investigated, resulting in the highest toxicity in digestive glands, followed by intestine, gill, mantle in both the hard clam and the surf clam.

On the other hand, it was confirmed that the toxins in all the bivalves tested were found to be composed mainly of GTX1, GTX2, GTX3, GTX4, PX2(C2) and a small amount of PX1(C1) from the HPLC analysis for PSP before and after hydrolysis of each sample. STXs were found to be not present in each bivalves from STXs analysis. But dissimilarity in PSP component of each species was found through investigated years. Especially, some difference among the species was recognized in the ratio of N1-OH carbamate toxin (GTX1, GTX4) to N1-H carbamate toxin (GTX2, GTX3); even in the same lot of the hard clam and the surf clam collected with the same net. In the mussel, epimeric N1-OH toxin GTX1 or GTX4 whose total is 80 mole\% or more was the major component. Also in the surf clam whose total is $60 \sim 70$ mole\% was the major. But, ratio of N1-H toxin (GTX2, GTX3) was found to be relatively high in comparison with that in the mussel. In the hard clam N1-H toxin GTX3 was the major: its mean was 40 mole\% or more. Moreover, similar difference in proportion of N1-OH toxin (GTX1, GTX4) to N1-H toxin (GTX2, GTX3) was also found in each proportion of the viscera and the muscle parts in the surf clam; the amount of N1-OH toxin (GTX1, GTX4) in viscera was much less than in the muscle. Although PSP composition of bivalve toxins seemed to reflect that of the causative dinoflagellate toxin especially in definite components of GTX1,2, 3, 4 and $\mathrm{PX}(\mathrm{C}) 1,2$, the species-specific differences in relative amount of the toxin component were recognized even in the same lot of different bivalves. In the surf clam, the anatomical variation of toxin composition was found, while in the mussel, no obvious variation was recognized. These findings suggest that the structure of PSP of toxic plankton ingested by bivalves is changed or modified in the viscera by

\begin{tabular}{lccccc}
\hline & $\mathrm{R}_{1}$ & $\mathrm{R}_{2}$ & $\mathrm{R}_{3}$ & $\mathrm{R}_{4}$ & Toxicity(MU/mg) \\
\hline STX & $\mathrm{H}$ & $\mathrm{H}$ & $\mathrm{H}$ & $\mathrm{CONH}_{2}$ & 5,500 \\
GTX1 & $\mathrm{OH}$ & $\mathrm{H}$ & $\mathrm{OSO}_{3}^{-}$ & $\mathrm{CONH}_{2}$ & 5,000 \\
GTX2 & $\mathrm{H}$ & $\mathrm{H}$ & $\mathrm{OSO}_{3}^{-}$ & $\mathrm{CONH}_{2}$ & 4,200 \\
GTX3 & $\mathrm{H}$ & $\mathrm{OSO}_{3}^{-}$ & $\mathrm{H}$ & $\mathrm{CONH}_{2}$ & 5,600 \\
GTX4 & $\mathrm{OH}$ & $\mathrm{OSO}_{3}^{-}$ & $\mathrm{H}$ & $\mathrm{CONH}_{2}$ & 1,600 \\
opiOTX8(C1.PX1) & $\mathrm{H}$ & $\mathrm{H}$ & $\mathrm{OSO}_{3}^{-}$ & $\mathrm{CONHSO}_{3}^{-}$ & $30-40$ \\
OTX8(C2.PX2) & $\mathrm{H}$ & $\mathrm{OSO}_{3}^{-}$ & $\mathrm{H}$ & $\mathrm{CONHSO}_{3}^{-}$ & $300-600$ \\
\hline
\end{tabular}

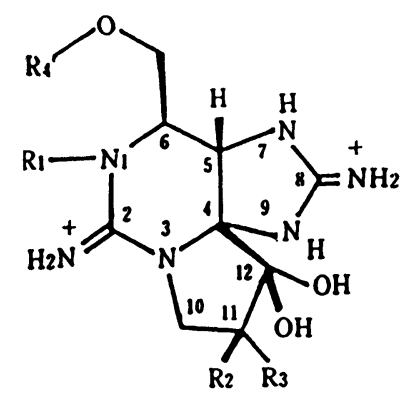

STX:eaxitoxin; GTX:gonyautoxin; PX:protogonyautoxin

Fig. 3 Structure of PSP. 
species-specific metabolism inclusive of excretion and adsorption. So is the case with the velocity of toxin accumulation and depuration.

Epimerization at $\mathrm{H}$ and $\mathrm{OSO}_{3}{ }^{-}$at $\mathrm{C}-11$ position of carbamate PSP occures in bivalves during their toxification and detoxification progress; the ratio of $\alpha$-epimer GTX1 to $\beta$-epimer GTX4 increased close to $3: 1$. The toxic dinoflagellate is thought to produce $\beta$-epimers of GTX 3,4 and $\mathrm{PX}(\mathrm{C}) 2$ by biosynthesis ${ }^{4}$. PSP ingested into bivalves seems to be transformed to chemically more stable $\alpha$-epimers gradually until near the equilibrium point. So, the ratio of $\alpha$ : $\beta$-epimer at a certain stage can provide information on the period from the beginning of toxification of bivalves. However, in the ratio of GTX2: GTX3, all bivalves tested showed only slight increase. The small amount of bases such as acetate is considered to enhance the epimerization of GTX2 to GTX3 $3^{5 \text { ) }}$.

In order to know real toxicity of the toxificated bivalves from a standpoint on food hygiene, determination of PSP composition is indispensable because PSP toxin components include very low toxic component transformable easily to the corresponding high toxic component.

\section{References}

1) Official Methods of Analysis 15th Ed., AOAC, Arlington, VA, $881-889$ (1990).

2) Life Health Bureau, Ministry of Health and Welfare of Japan ed. "Shokuhin Eisei Kensa Shishin", 300305 (1991), Japan Food Hygiene Association, Tokyo.

3) Nagashima, Y., Maruyama, j., Noguchi, T., Hashimoto, K. : Nippon Suisan Gakkaishi 53, 819-823 (1987).

4) Oshima, Y., Bolch, C. J., Hallegraeff, G. M.: Toxicon 30, 1539-1544 (1992)

5) Shimizu, Y.: "Progress in the Chemistry of Organic Natural Products" 45, p. 235-964 (1984), Herz, W., Greisebach, H., Kirby, G. W. (Eds), Springer-Verlag, Wien. 